\title{
Application of Ecotoxicological Tests in a Preliminary Evaluation of Soils Treated on Bioreactor
}

\author{
C. L. S. Sisinno, ${ }^{1 *}$ A. C. L. Rizzo, ${ }^{2}$ M. R. M. Bulus, ${ }^{3}$ \\ D. A. Rocha, ${ }^{2}$ A. U. Soriano, ${ }^{4}$ R. L.Vital ${ }^{4} \&$ J. C. Moreira ${ }^{5}$ \\ ${ }^{1}$ BfU do Brasil Environmental Services Ltda., Manoel de Carvalho, 16, 10 ${ }^{\text {th }}$ floor, \\ CEP 20031-110, Centro, Rio de Janeiro, RJ, Brazil \\ ${ }^{2}$ Ministry of Science and Technology, Center for Mineral Technology (CETEM), \\ Av. Ipê, 900, Brazil, CEP 21941-590, Ilha do Fundão, Rio de Janeiro, RJ, Brazil \\ ${ }^{3}$ Rio de Janeiro Environmental Agency, Ecotoxicology Sector (FEEMA), \\ Av. Salvador Allende, 500, Brazil, CEP 22780-160, Jacarepaguá, Rio de Janeiro, RJ, Brazil \\ ${ }^{4}$ PETROBRAS' Research and Development Center (CENPES), Biotechnology and \\ Environmental Treatment Section, Av. Jequitibá, 950, CEP 21941-598, Ilha do Fundão, Rio de Janeiro, RJ, Brazil \\ ${ }^{5}$ Ministry of Health, Oswaldo Cruz Foundation (FIOCRUZ), National School of \\ Public Health, Leopoldo Bulhões, 1480, CESTEH, CEP 21041-210, Manguinhos, Rio de Janeiro, RJ, Brazil
}

(Received July 06, 2006; Accepted June 17, 2007)

\begin{abstract}
Bioremediation processes are being applied nowadays for treatment of contaminated soils by petroleum products. However, only chemical analyses are used for efficiency verification, without taking into account a biological indicator. The aim of this work was the application of two ecotoxicological tests for the evaluation of a soil contaminated by crude oil, after treatment on a bioreactor, in different conditions. Sample A was treated with biostimulation $(\mathrm{pH}$, nutrients and moisture control), while samples B and C, besides biostimulation was applied bulking material (sawdust; 10\% w/w) also. The ecotoxicological tests chosen were luminescent bacteria Vibrio fischeri (ISO 11348-3:1998) and an avoidance behavior test with Eisenia fetida earthworms (still in a draft form). This test consists in the exposition of the organisms to contaminated soil and control soil samples, simultaneously, to evaluate the percentage of organisms that goes from the center of the recipient to the control sample sector. The results of avoidance behavior tests of samples A, B and C were, respectively, $52 \%, 29 \%$ and $50 \%$. Those results indicate no toxicity, once the criteria for a sample be considered toxic is that more than $80 \%$ of the total exposed organisms are in the control soil at the end of the test. However, the test with Vibrio fischeri indicated toxicity for sample B $\left(\mathrm{CE}_{50} 13.8 \%\right)$, probably because of the recent contamination. Those results indicate that, although the importance of ecotoxicological tests inclusion for the complementation of bioremediation processes evaluation, at least two tests, using different organisms must be performed for a better consideration.
\end{abstract}

Key words: soil contamination, bioremediation, bioreactor, ecotoxicological tests.

\section{RESUMO}

\section{Aplicação de ensaios ecotoxicológicos na avaliação preliminar de solos tratados em biorreator}

Os processos de biorremediação têm sido muito utilizados atualmente para o tratamento de solos contaminados por derivados da indústria do petróleo. Entretanto, apenas as análises químicas são usadas para verificação da eficiência do processo, sem a inclusão de um indicador biológico. O objetivo deste trabalho foi aplicar dois ensaios de toxicidade para avaliar um solo contaminado com óleo cru após tratamento em biorreator, em diferentes condições. A amostra A foi tratada em biorreator com a aplicação de bioestímulo (controle de $\mathrm{pH}$, nutrientes e umidade), enquanto nas amostras $\mathrm{B}$ e $\mathrm{C}$, além

*Corresponding author: Cristina L. S. Sisinno, e-mail: cristina.sisinno@uol.com.br. 
do bioestímulo, houve adição de material estruturante (serragem). Os ensaios de toxicidade escolhidos foram com bactérias luminescentes Vibrio fischeri (ISO 11348-3:1998) e um ensaio de comportamento de fuga com minhocas da espécie Eisenia fetida (ainda sob forma de draft da ISO), que consiste na exposição das amostras do solo que será avaliado e do solocontrole, simultaneamente, para avaliar o percentual de organismos que se desloca do centro do recipiente-teste para a área do solo-controle. Os resultados para o ensaio de fuga das amostras A, B e C foram, respectivamente, $52 \%, 29 \%$ e $50 \%$. Esses resultados não indicaram toxicidade, uma vez que o critério para uma amostra ser considerada tóxica é que mais de $80 \%$ do total de organismos esteja no solo-controle ao final do ensaio. Entretanto, o ensaio com Vibrio fischeri indicou toxicidade para a amostra $\mathrm{B}\left(\mathrm{CE}_{50} 13,8 \%\right)$. Esses resultados sugerem que, além da importância da inclusão dos ensaios ecotoxicológicos para complementação da avaliação de processos de biorremediação, devem ser realizados pelo menos dois ensaios com organismos diferentes para melhor consideração sobre a avaliação ecotoxicológica das amostras.

Palavras-chave: contaminação do solo, biorremediação, biorreator, ensaios ecotoxicológicos.

\section{INTRODUCTION}

By definition, bioremediation is the use of living organisms, primarily microorganisms, to degrade the environmental contaminants into less toxic forms. It uses naturally occurring bacteria and fungi or plants to degrade or detoxify substances hazardous to human health and/or the environment (Vidali, 2001).

For bioremediation to be effective, microorganisms must enzymatically attack the contaminants and convert them to harmless products. As bioremediation can be effective only where environmental conditions permit microbial growth and activity, its application often involves the manipulation of environmental parameters to allow microbial growth and degradation to proceed at a faster rate (Vidali, 2001).

Different techniques are employed in bioremediation processes. In situ bioremediation provides the treatment in place, for example: bioventing, in situ biodegradation and biosparging. Ex situ bioremediation techniques involve the biological treatment after the excavation or removal of contaminated soil from ground. For example, landfarming, biopiles and bioreactors (Vidali, 2001).

In a bioreactor, that could be a slurry-phase or a solidphase bioreactor, the operating parameters have to be optimized in order to reduce costs and increase efficiency (Nano et al., 2003). Both the reactors involve the contact of the contaminated soil with water, nutrients, oxygen, biomass, bulking agents and occasionally cosubstrates or surfactants to enhance the biodegradation rate. However, while in a slurry-phase bioreactor the soil is suspended in water, in the solid-phase bioreactor water is just added to ajust the soil moisture content to support microbial growth and maintenance.

Bioremediation is being used nowadays in the treatment of soils contaminated by petroleum industry but the contamination assessment has been focused only on chemical parameters, without taking into account ecotoxicological tests. However, the chemical analysis of the substances cannot provide the toxicity information for living organisms. The ecotoxicological tests can indicate a more precise response of contaminants toxicity for living organisms that a chemical analyses of each compound could not do.
Studies performed after remediation processes by hydrocarbons showed that a residual toxicity could be present, demonstrated only by ecotoxicological tests (Dorn \& Salanitro, 2000; Hund \& Traunspurger, 1994; Nunes-Halldorson et al., 2004; Plaza et al., 2005; Salanitro et al., 1997). Some byproducts and intermediates can be generated by the microbiological activity during the bioremediation processes and could be more toxic than the initial contaminants (NunesHalldorson et al., 2004).

Once recent studies have added toxicity effects of bioremediation, a group of ISO (International Organization for Standardization) experts is preparing some recommendations for test strategies with respect to the protection of the habitat function of soil. The tests recommended represent a minimum test battery that may be accomplished by additional tests or even be replaced by others according to the intended uses or protection goals envisaged (ISO, 2006b). It is well known that ecotoxicity of contaminants in soil samples are different for various organisms, so the spectrum of test organisms should encompass different trophic levels. As reported by Hubálek et al. (2007), ecotoxicity tests of soil samples can be performed either as contact tests with solid material or as tests on soil elutriates. Luminescent bacteria (Vibrio fischeri) test is one of the most commonly and recommended to assess the retention function of soil extracts (ISO 11348:1998, all parts). Their sensitivity, however, is lower for substances with low water solubility, as petroleum hydrocarbons.

There are several standardized contact tests, but Eisenia fetida is a frequently used test organism for soil quality assessments. Originally, the earthworm mortality test (ISO 11268-1) and the reproduction test (ISO 11268-2) were developed for substance testing (ISO, 1998a and b). These tests can be applied to investigate the habitat function of a soil for soil biocenosis with respect to earthworms. The disadvantages of the acute test and the reproduction test are a low sensitivity and a long test period (Hund-Rinke et al., 2002). As the test period and the work expense dictate the costs of a given test, it is preferable to obtain the results within a short test period and at a high level of sensibitily. That is especially the case for assessment of remediated soils (ISO, 2006a). 
For this fact, some researchers (Hund-Rinke \& Wiechering, 2001; Hund-Rinke et al., 2002, 2005; Loureiro et al., 2005; Schaefer, 2001) are evaluating a test using earthworms (Eisenia fetida and E. andrei) - that is still in a draft form - where the avoidance behavior is used as indicator (ISO, 2006a). The avoidance behavior test may be applied as a rapid screening test to determine the bioavailability of chemical substances or of contaminants in the soil for Eisenia sp., and can be used for soil contamination and soil remediation samples.

The aim of this work was the application of two ecotoxicological tests using Vibrio fischeri for determination of the inhibitory effect on the light emission and Eisenia fetida behavior test for the evaluation of a soil contaminated by crude oil, after treatment on a solid-phase bioreactor, in different conditions. The Vibrio fischeri test was chosen because it is being indicated on the ISO/CD 17616 Draft - Guidance for the choice and evaluation of bioassays for ecotoxicological characterization of soils and soil material (ISO, 2006b) as one of the aquatic test with soil eluate that can be applied to obtain information about the fraction of contaminants potentially reaching the groundwater by the water path (retention function of soils). The avoidance behavior test with E. fetida was chosen because it is being indicated as suitable especially in cases for the assessment of remediated soils (ISO, 2006a).

\section{MATERIAL AND METHODS}

The soils used for this study were from Brazil, contaminated with crude oil $(2-4 \% \mathrm{w} / \mathrm{w})$ that were, before the biological treatment, naturally-dried, sieved to pass a $1.68 \mathrm{~mm}$ sieve and homogenized. The background characteristics of the contaminated soils are presented in Table 1 .

Contaminated soil samples were treated on a solid-phase bioreactor during 42 days at ambient temperature and daily submitted to agitation and aeration cycles. Sample A was treated with biostimulation ( $\mathrm{pH}$, nutrients and moisture control), while samples B and C, besides biostimulation was applied bulking material (sawdust; $10 \% \mathrm{w} / \mathrm{w}$ ) also.

As could be verified in Table 2, at the end of the treatment all samples showed satisfactory results in terms of total petroleum hydrocarbon (TPH) removal: sample A 12.5\%; sample B $13.0 \%$; and sample C $36.3 \%$. Those results are considered satisfactory since only 5 to $7 \% \mathrm{TPH}$ removal were obtained in a 42 day monitored natural attenuation process simulation, conducted by the authors as a control, for the same contaminated soil samples (data not shown).

The ecotoxicological tests chosen were luminescent bacteria Vibrio fischeri (ISO 11348-3) and the avoidance behavior test with Eisenia fetida (Draft ISO/DIS 17512-1.2)(ISO, 1998c; ISO 2006a). The bioassay with Vibrio fischeri has been used for ecotoxicity evaluation of contaminated soil (Hubálek et al., 2007) and frequently recommended by Brazilian environmental agencies as a complementary biological parameter. Nevertheless, Eisenia fetida is a widespread earthworm species routinely used in ecotoxicological studies, including waste site assessments (Hubálek et al., 2007). Soils samples were dried and sieved through a $2 \mathrm{~mm}$ mesh before Vibrio fischeri test, conducted based on EPA-823/B-01-002 method (EPA, 2001). The soil elutriate was prepared by mixing the soil (on dry mass basis) with distilled water (1:4 w/v, soil:water) and shakering during $30 \mathrm{~min}$., following by centrifugation for $30 \mathrm{~min}$.

Table 1 - Background characteristics of the contaminated soils.

\begin{tabular}{ccc}
\hline Characteristics & Soil A and B & Soil C \\
\hline Soil texture & Sandy loam & Loamy sand \\
Soil horizon & A & A \\
Contamination type & Paraffinic crude oil & Paraffinic crude oil \\
Contamination & Former/recent & Former \\
Water holding capacity $(\mathrm{WHC})(\%)$ & 28 & 27 \\
$\mathrm{pH}$ & 6.4 & 4.8 \\
Bulk density $\left(\mathrm{g} / \mathrm{cm}^{3}\right)$ & 1.2 & 1.1 \\
Particle density $\left(\mathrm{g} / \mathrm{cm}^{3}\right)$ & 1.4 & 2.3 \\
Porosity $(\%)$ & 16.5 & 52 \\
\hline
\end{tabular}


The principle of ISO 11348-3 is the inhibition of light emission by cultures of Vibrio fischeri by means of a batch test. This is accomplished by combining specified volumes of the test sample or the diluted sample with the luminescent bacteria suspension in a cuvette. The test criterion is the decrease of the luminescence, measured after a contact of $15 \mathrm{~min}$ and $30 \mathrm{~min}$, taking into account a correction factor $\left(f_{\mathrm{kt}}\right)$, wich is a measure of intensity changes of control samples during the exposure time. The results were expressed in $\mathrm{CE}_{50}$ (ISO, 1998c).

The soils samples used for avoidance behavior test were previously sieved $(2 \mathrm{~mm})$ and adjusted to about $60 \%$ of the maximum water holding capacity. The control soil used was a soil as similar as the test soil in all characteristics other than the presence of contaminants, taked from the surroundings (ISO, 2006a).

The avoidance behavior test was performed with the exposure of the earthworms at the same time to the samples of non contaminated (control) and treated soil. Both samples are placed in the same recipient, in different sections, separated through a divider, forming two compartments. After organizing the samples on each side, the divider is removed, forming a line where 10 adult organisms (with developed clitellum and wet mass between $300 \mathrm{mg}$ and $600 \mathrm{mg}$ ) are placed in the surface (ISO, 2006a).

After 48 hours, the number of organisms in each section of the recipient is verified. The sample is considered to be toxic (with the habitat function limited) if more than $80 \%$ of the total of exposed organisms were found in the control soil. The results were expressed by percentage of organisms in the control soil (ISO, 2006a).

The tests were performed with five replicates, and were developed in controlled conditions of temperature $\left(20^{\circ} \mathrm{C} \pm 2^{\circ} \mathrm{C}\right)$, constant light intensity (400 lux to 800 lux), and light/dark cycle (12 h:12 h). The reference substance used to obtain general information about the sensitivity of the organisms was boric acid $\left(\mathrm{H}_{3} \mathrm{BO}_{3}\right)$ (ISO, 2006a).

\section{RESULTS}

The results of avoidance behavior tests of samples A, $\mathrm{B}$ and $\mathrm{C}$ were, respectively, 52\%, 29\% and 50\%. Those results indicated no toxicity, once the criteria for a sample be considered toxic is that more than $80 \%$ of the total exposed organisms are in the control soil at the end of the test.

The test with Vibrio fischeri indicated no toxicity for samples $\mathrm{A}\left(\mathrm{CE}_{50} 90 \%\right)$ and $\mathrm{C}\left(\mathrm{CE}_{50} 54.9 \%\right)$. However, sample $\mathrm{B}$ was considered toxic showing a $\mathrm{CE}_{50}$ of $13.8 \%$.

The ecotoxicological tests results are probably related with the time of contamination once sample B was originated from a recent case of contamination, where the supposed toxic by-products generated during the bioremediation were more available for the microorganisms.

\section{DISCUSSION}

The preliminary results indicated the importance of ecotoxicological tests application in the complementation of bioremediation processes evaluation. Besides this observation, at least two tests, using different organisms must be performed for a better consideration of the ecotoxicological evaluation of the soil samples. Hubálek et al. (2007) affirms that the results of ecotoxicological tests differs according to the test organisms, the selected endpoints and the type of test method (elutriates or contact test). 
Luminescent bacteria test can be recommended to assess the retention function of soil in cases where the potentially harmful substances in the contaminated soil can affect the ground and surface water (ISO, 2006b).

Avoidance behavior test performed with $E$. fetida adapted with the use of contaminated natural soils - may be applied in addition to contaminated areas evaluation. According to the results of Hund-Rinke \& Wiechering (2001), the avoidance behavior test with samples of contaminated areas showed a significantly larger sensibility compared to those with artificially contaminated samples. However, it should be pointed out that variations related with the composition of the soil to be tested need to be very carefully evaluated if the objective of the test is the evaluation of the toxicity with natural samples, without mixture with artificial soil.

This test may be applied in the evaluation of ecological risk to verify the degree of harm to the organisms that represent the affected ecosystem and their capacity of finding conditions of settling down again in an area affected by chemical contamination, as well as in the evaluation of the capacity of ecological recovery of an area, after a remediation process.

Acknowledgements - Our sincere gratefulness for the support given by FIOCRUZ/FAPERJ, PETROBRAS, Jörg Römbke from ECT Oekotoxikologie GmbH (Alemanha) and Jorge Luiz Florindo da Cruz of CETEM. JCM thanks the support of CNPq.

\section{REFERENCES}

DORN, P. B. \& SALANITRO, J. P., 2000, Temporal ecological assessment of oil contaminated soils before and after bioremediation. Chemosphere, 40: 419-426.

EPA(UNITED STATES ENVIRONMENTAL PROTECTION AGENCY), 2001, Methods for collection, storage and manipulation of sediments for chemical and toxicological analyses - Technical Manual. EPA 823/B01-002. [www.epa.gov/waterscience/cs/collectionmanual.pdf].

HUBÁLEK, T., VOSÁHLOVÁ, S., MATEJU, V., KOVÁCOVÁ, N. \& NOVOTONY, C., 2007, Ecotoxicity monitoring of hydrocarboncontaminated soil during bioremediation: a case study. Arch. Environ. Contam. Toxicol., 52: 1-7.

HUND, K. \& TRAUNSPURGER, W., 1994, Ecotox evaluation strategy for soil bioremediation exemplified for a PAH contaminated site. Chemosphere, 29: 371-390.

HUND-RINKE, K. \& WIECHERING, H., 2001, Earthworm avoidance test for soil assessments: an alternative for acute and reproduction tests. $J$. Soils \& Sediments, 1: 15-20.

HUND-RINKE, K., ACHAZI, R., RÖMBKE, J. \& WARNECKE, D., 2002, Avoidance test with Einsenia fetida as indicator for the habitat functions of soils: results of a laboratory comparison test. J. Soils \& Sediments, 3: $1-6$.
HUND-RINKE, K., LINDEMANN, M \& SIMON, M., 2005, Experiences with novel approaches in earthworm testing alternatives. J. Soils \& Sediments, 5: 233-239.

ISO (INTERNATIONAL ORGANIZATION FOR STANDARDIZATION), 1998a, ISO 11268-1. Soil quality - Effects of pollutants on earthworms (Eisenia fetida). Part 1: Determination of acute toxicity using artificial soil substrate. ISO, Geneva, 6p.

ISO (INTERNATIONAL ORGANIZATION FOR STANDARDIZATION), 1998b, ISO 11268-2. Soil quality - Effects of pollutants on earthworms (Eisenia fetida). Part 2: Determination of effects on reproduction. ISO, Geneva, 16p.

ISO (INTERNATIONAL ORGANIZATION FOR STANDARDIZATION), 1998c, ISO 11348-3. Water quality - Determination of the inhibitory effect of water samples on the light emission of Vibrio fischeri (Lumescent bacteria test) - Part 3: Method using freeze-dried bacteria. ISO, Geneva, $13 \mathrm{p}$.

ISO (INTERNATIONAL ORGANIZATION FOR STANDARDIZATION), 2006a, ISO/DIS 17512-1.2. Draft. Soil quality - Avoidance test for testing the quality of soils and effects of chemicals on behavior - Part 1: Test with earthworms (Eisenia fetida and Eisenia andrei). ISO, Geneva, 26p.

ISO (INTERNATIONAL ORGANIZATION FOR STANDARDIZATION), 2006b, ISO/CD 17616. Draft. Soil quality - Guidance for the choice and evaluation of bioassays for ecotoxicological characterization of soils and soil material. ISO, Geneva, 11p.

LOUREIRO, S., SOARES, A. M. V. M. \& NOGUEIRA, A. J. A., 2005, Terrestrial avoidance behavior tests as screening tool to assess soil contamination. Environ. Poll., 138: 121-131.

NANO, G., BORRONI, A. \& ROTA, R., 2003. Combined slurry and solidphase bioremediation of diesel contaminated soils. J. Haz. Mat., B100: 79-94.

NUNES-HALLDORSON, V. S., STEINER, R. L. \& SMITH, G. B., 2004 Residual toxicity after biodegradation: Interaction among benzene, toluene, and chloroform. Ecotox. and Environ. Safety, 57: 162-167.

PLAZA, G., NALECZ-JAWECKI, G., ULFIG, K. \& BRIGMON, R. L., 2005, The application of bioassays as indicator of petroleum-contaminated soil remediation. Chemosphere, 59: 289-296.

SALANITRO, J. P., DORN, P. B., HUESEMANN, M. H., MOORE, K. O., RHODES, I. A., JACKSON, L. M., VIPOND, T. E., WESTERN, M. M. \& WISNIEWSKI, H. L., 1997, Crude oil hydrocarbon bioremediation and soil ecotoxicity assessment. Environ. Sci. Technol., 31: 1769-1776.

SCHAEFER, C., 2001, Earthworm in crude oil contaminated soils: toxicity tests and effects on crude oil degradation. Contam. Soil, Sed. \& Water, 8: 35-37.

VIDALI, M., 2001, Bioremediation: an overview. Pure Appl. Chem., 73 1163-1172. 
